\title{
Norwegian farmers ceasing certified organic production: Characteristics and reasons
}

\author{
Ola Flaten ${ }^{\mathrm{a}, *}$, Gudbrand Lien ${ }^{\mathrm{a}, \mathrm{b}}$, Matthias Koesling ${ }^{\mathrm{c}}$, Anne-Kristin Løes ${ }^{\mathrm{c}}$ \\ ${ }^{a}$ Norwegian Agricultural Economics Research Institute, Box 8024 Dep., NO-0030 Oslo, Norway \\ ${ }^{\mathrm{b}}$ Faculty of Economics and Organisation Science, Lillehammer University College, Box 952, NO-2604 Lillehammer, Norway \\ ${ }^{\mathrm{c}}$ Bioforsk Organic Food and Farming Division, Norwegian Institute for Agricultural and Environmental Research, Gunnars Veg 6, NO-6630 Tingvoll, Norway
}

\section{A R T I C L E I N F O}

Article history:

Received 2 November 2009

Received in revised form

14 June 2010

Accepted 19 July 2010

Available online 10 August 2010

\section{Keywords:}

Organic farming

Deregister

Certification

Environmental attitude

Survey

Multivariate analysis

\begin{abstract}
A B S T R A C $T$
This article examines the characteristics of and reasons for Norwegian farmers' ceasing or planning to cease certified organic production. We gathered cross-sectional survey data in late 2007 from organic farmers deregistering between January 2004 and September $2007(n=220)$, and similar data from a random sample of farmers with certified organic management in $2006(n=407)$. Of the respondents deregistering by November $2007,17 \%$ had quit farming altogether, $61 \%$ now farmed conventionally, and $21 \%$ were still farming by organic principles, but without certification. Nearly one in four organic farmers in 2007 indicated that they planned to cease certification within the next 5-10 years. From the two survey samples, we categorised farmers who expect to be deregistered in 5-10 years into three groups: conventional practices $(n=139)$, continuing to farm using organic principles (uncertified organic deregistrants, $n=105)$, and stopped farming $(n=33)$. Of the numerous differences among these groups, two were most striking: the superior sales of uncertified organic deregistrants through consumer-direct marketing and the lowest shares of organic land among conventional deregistrants. We summarised a large number of reasons for deregistering into five factors through factor analysis: economics, regulations, knowledge-exchange, production, and market access. Items relating to economics and regulations were the primary reasons offered for opting out. The regression analysis showed that the various factors were associated with several explanatory variables. Regulations, for example, figured more highly among livestock farmers than crop farmers. The economic factor strongly reflected just a few years of organic management. Policy recommendations for reducing the number of dropouts are to focus on economics, environmental attitudes, and the regulatory issues surrounding certified organic production.
\end{abstract}

(c) 2010 Elsevier Ltd. All rights reserved.

\section{Introduction}

Organic production in many Western countries has grown rapidly in recent years. However, this growth has occurred under different policies. European governments have actively promoted organic farming through payments to farmers in the belief that it provides public environmental and social benefits (e.g., Stolze and Lampkin, 2009). In the United States, federal organic policy was, until recently, oriented towards using market-mechanisms. In 2008, however, the Farm Bill for the first time provided financial support to farmers to convert to organic production. Further initiatives to support organic production were announced in 2009 (Constance and Choi, 2010).

\footnotetext{
* Corresponding author. Tel.: +47 624871 00; fax: +47 22367299.

E-mail addresses: ola.flaten@nilf.no (O. Flaten), gudbrand.lien@hil.no (G. Lien), matthias.koesling@bioforsk.no (M. Koesling), anne-kristin.loes@bioforsk.no (A.-K. Løes).
}

To reach the targets for organic production set by many European governments (e.g., Willer and Kilcher, 2010), there is a need for more farmers to convert. The literature has identified a wide range of barriers to organic conversion, such as institutional, technical and individual factors, and lack of information and experience (e.g., Constance and Choi, 2010). Business agendas, lifestyle choices and environmental issues are found to be important for a farmer's decision to convert to organic farming (e.g. Koesling et al., 2008; Rigby et al., 2001; Toma and Mathijs, 2007).

As more farmers have established organic production systems, a large number have also ceased organic certification, choosing instead to stop farming altogether, to farm conventionally, or to farm by organic principles but without certification. ${ }^{1}$ To develop

\footnotetext{
${ }^{1}$ In Norway (and other countries with legislative protection of the term 'organic'), producers farming by organic principles but without certification are not permitted to make any sort of organic claim.
} 
appropriate policies for reducing the number of deregistrants, governments need to know why some farmers have ceased to uphold their certification. The literature on the opting-out phenomenon is, however, rather sparse.

A study of 35 horticultural producers in the United Kingdom who opted out between 1990 and 1998 identified the lack of market outlets as the most important reason (Rigby et al., 2001). In a later UK study including interviews of 22 quitters, Harris et al. (2008) recorded financial reasons to be dominant and often compounded by difficulties associated with the certification process or an unrealistic expectation of what organic farming would entail. Economic issues were also the main reasons for 150 Austrian farmers to think about ceasing organic farming in 1999, whereas problems concerning organic guidelines and inspections were more prominent in the actual decision, as cited in interviews with 13 farmers in 2004 (Kirner et al., 2006). In Denmark, 11 farmers interviewed in 2003 ceased to farm organically owing to economic issues, primarily problems with marketing and changed regulations (Kaltoft and Risgaard, 2006). A mail survey of 77 Californian deregistrants in 2003-2005 showed that 35\% had quit farming altogether (Sierra et al., 2008). Of those still farming, 60\% had reverted to conventional practices, while $40 \%$ retained organic methods. The principal reason for ceasing organic registration was regulatory issues.

The reviewed studies have typically included small samples, and there is a dearth of studies exploring the profiles of various groups of deregistrants (i.e., stopped farming, still farming, conventionally or by organic principles). Statistical studies applied to large samples allow for the establishing of relationships among variables, and they are essential for understanding the degree to which certain characteristics are present in groups or how they vary across individuals (e.g., Flyvbjerg, 2006). The present state of knowledge suggests that large random samples or entire populations of deregistrants deserve to be explored by surveys with related multivariate analysis. In addition, there appears to be limited information about the prospects of established organic farmers who are continuously considering whether to extend their certification. Their choices are important for the future prospects of the organic sector.

This study aims to examine statistically the characteristics of and reasons for Norwegian farmers' ceasing or planning to cease certified organic production. We address the following research questions: (1) are many organic farmers planning to cease certified organic production within the next 5-10 years? (2) Will deregistrants leave farming altogether, or will they still farm, conventionally or by organic principles? (3) What are the socio-demographic and farm-production attributes, and the environmental attitudes that characterise the various groups of deregistrants? (4) What are the farmers' reasons for ceasing certified organic production? (5) What attributes are associated with the different reasons for opting out? This inquiry will help draw out implications for policymakers seeking to expand organic production.

\section{A brief overview of organic farming in Norway}

Although organic farming in Norway started little by little in the 1930 's, only since the early 1990s Norway has encouraged organic production through a broad range of policies by means of legal, financial, and communicative instruments. Conversion and maintenance payments for organic farmland have been available since 1990, and organic livestock payments since $2001 .^{2}$ For a further description, see Flaten et al. (2006).

\footnotetext{
${ }^{2}$ The specific organic farming payments constitute approximately $1.5 \%$ of budgetary support to farmers.
}

All products have to be certified organic in order to be labelled and sold as organic and to obtain an organic price premium. In Norway, certification is required for receiving organic farming payments. A private-membership organisation, Debio, has been accredited to carry out the organic inspections and certifications. ${ }^{3}$ Debio-inspectors visit organic farmers annually to ensure that they meet government standards. Although Norway is not a member of the European Union (EU), the Norwegian standards (Mattilsynet, 2009) accord with EU legislation for organic production because this subject has been included in the Agreement on the European Economic Area, of which Norway is a member. Conversion of the farm over successive years and partial farm conversion are allowed, while parallel production of the same variety of crops and management of organic and non-organic livestock of the same species on the same holding are not.

The number of certified organic farms in Norway has grown from 423 in 1991 via 1840 in 2000 to 2851 in 2009 (Debio, 2010), i.e., a slower expansion in the 2000s compared to the 1990s. In 2009, there were 43,986 ha of converted organic land in Norway, equal to $4.3 \%$ of the agricultural area of the country, and organic food represented $1.2 \%$ of total food retail sales (SLF, 2010). Current growth rates are small compared to the public target of a $15 \%$ organic share of the Norwegian food production and consumption by 2020 (LMD, 2009).

Since 2002, 150-400 farmers have established organic production each year (Fig. 1). At the same time, about 150-200 farmers cease their certification annually, implying a 6-7\% turnover rate among organic farmers. Between 2004 and 2006, the number of exits nearly equalled entries, and the expansion of organic and in-conversion land was small.

\section{Materials and methods}

\subsection{Sampling and data collection}

The study was based on a farmer survey merged with data (1995-2006) from SLF (Norwegian Agricultural Authority). The SLF-register includes data on farmland used for the cultivation of various crops and livestock numbers on all Norwegian farms entitled to governmental payments. By 2006, SLF kept records for 48,811 farmers.

We pre-tested the questionnaire on seven current or former organic farmers and five agricultural experts and refined it over several stages. The structured questionnaire was mailed in November 2007 to 523 farmers who had ceased organic certification between January 2004 and September 2007. These are all deregistered farmers in the period, ${ }^{4}$ except for 123 farmers whose sales were too small to justify governmental support payments (annual farm sales needed to exceed NOK $^{5} 30,000$ ).

We also sent the survey to 620 farmers receiving organic farming payments in 2006 . This group formed a randomly selected sample of the totally 1913 organic farmers in the SLF-register. We required these respondents to have at least 1 ha of converted organic land or at least five organic dairy cows by 2006.

\footnotetext{
3 There are three kinds of certification: first-, second- and third-party. First-party certification refers to self-audits by suppliers, second-party certification to audits by buyers, and third-party certification (TPC) to audits by independent bodies. TPC regulates organic agriculture in Norway, encompassing the strict separation of inspection and advice.

4 There may be differences between voluntarily deregistrants and those that may be forced to deregister through infringement of organic farming standards. In Norway, these few farmers are usually enabled to put matters straight. If they refrain, they are regarded as deregistered. Therefore, we did not distinguish between the two forms of deregistration.

${ }^{5}$ Norwegian kroner, $100 \mathrm{NOK} \approx € 12.50$.
} 


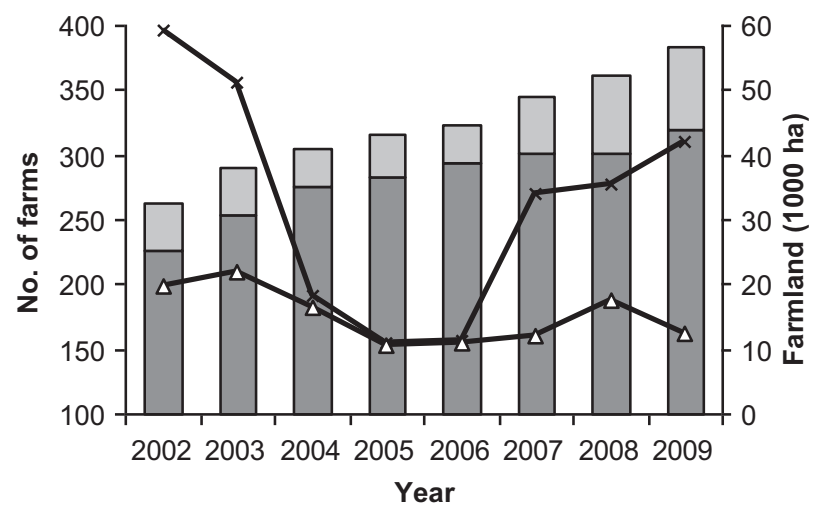

$\checkmark$ Converted land $\square$ In-conversion $\longrightarrow$ In $\triangle$ Out

Fig. 1. Number of farmers registering and deregistering with Debio and hectares of organic and in-conversion land in Norway. Source: Debio (2010).

Of all the questionnaires sent, 45 to the deregistrants and one to the organic farmers were returned undeliverable. After two reminders, we obtained 245 deregistered and 419 current organic questionnaires, and ended up with a $51 \%$ response rate (245 from 478 ) for the deregistrants and 68\% (419 from 619) for the organic farmers. We discarded 25 deregistrant and 12 organic surveys who filed missing information returns of more than one-third of the variables. In total, 627 respondents provided sufficient data for further analysis.

\subsection{Instruments}

The questionnaire covered a wide range of issues, such as farming status, plans about future organic certification, organic farming experience, farmer characteristics, measures of environmental attitudes, and reasons for ceasing organic production. Farmers indicated their current farming status by selecting one of four options: (1) organic certified, (2) deregistered, still farming by organic principles, (3) deregistered, farming using conventional practices, and (4) deregistered, stopped farming. We gave the same alternatives to those currently practising organic farming for their plans for the farm 5-10 years ahead.

The revised New Ecological Paradigm (NEP) Scale, originally consisting of 15 items (Dunlap et al., 2000), is widely used to measure environmental attitudes. To compress the questionnaire, we used a shorter version of eight items (Appendix A), which has worked well in Norwegian studies (e.g., Skogen and Thrane, 2008). The scale items have a balance of pro- and anti-NEP statements. We measured the NEP-items on a seven-point Likert-scale (1 strongly disagree/7 - strongly agree).

Table 1 provides a description of variables from the SLF-register and the questionnaire that will be used in this study, except the 27 items to measure the reasons for ceasing organic certification (see Section 4.5). We reviewed previous studies to identify these items, which were again scored on seven-point Likert-scales (1 - not important/7 - very important). The questions about reasons for opting out were only posed to those respondents indicating they would not be certified organic in 5-10 years. As an open final question, respondents could describe in their own words why they ceased organic farming or to comment on other aspects of the survey.

\subsection{Empirical framework}

We categorised the farmers in the two survey samples who indicated that they will not be certified organic in 5-10 years' time into three groups for all parts of the analysis (except for the current farming status in Section 4.1): (1) farming by organic principles, but

Table 1

Overview of key characteristics and environmental attitudes selected from the questionnaire (a) and the SLF-register ${ }^{\mathrm{a}}$ (b).

\begin{tabular}{|c|c|}
\hline Variable & Description \\
\hline \multicolumn{2}{|l|}{ (a) } \\
\hline Age & Age of the farm operator in years. \\
\hline Year of conversion & The year of organic certification of the first field(s) on the farm. \\
\hline Female & 1 for female operator, 0 otherwise. \\
\hline Education & 1 for an operator with a bachelor degree or higher, 0 otherwise. \\
\hline Agricultural education & 1 for an operator with agricultural education, 0 otherwise. \\
\hline Extension service member & 1 for membership in the Agricultural Extension Service, 0 otherwise. \\
\hline Location & 1 for a central location (no regional policy priority, Flaten et al. (2005)), 0 otherwise. \\
\hline Off-farm work & $\begin{array}{l}1 \text { for a holding where a single farmer or both the farmer and his/her partner have at least } \\
15 \% \text { off-farm work positions, } 0 \text { otherwise. }\end{array}$ \\
\hline High farm income & $\begin{array}{l}1 \text { for a farm household with farm income higher than NOK } 300000 \text { in } 2006,0 \text { otherwise. Farm income represents the } \\
\text { return to all unpaid labour and management and all capital invested in the farm. }\end{array}$ \\
\hline Consumer-direct marketing & Percentage of total sales through consumer-direct marketing. \\
\hline NEP-scale & Summated scale based on responses presented in Appendix A. \\
\hline \multicolumn{2}{|l|}{ (b) } \\
\hline Farmland & Farmland is measured in operated hectares (ha). Land in conversion is included in organic farmland areas. \\
\hline Organic horticulture & Farms with more than 0.2 ha of organic potatoes, vegetables, fruit or berries. \\
\hline Organic grains & Farms with more than 1 ha of organic grains and oilseeds. \\
\hline Organic forage crops & Farms with more than 1 ha of organic grasslands. \\
\hline Stocking rate & $\begin{array}{l}\text { Livestock units (LU) per ha utilisable agricultural area (UAA). Figures are based on livestock numbers and } \\
\text { hectares from SLF. }\end{array}$ \\
\hline Dairy & Farms with dairy cows. \\
\hline Sheep & Farms with more than 5 ewes older than 1 year at the start of the calendar year. \\
\hline Farm type & $\begin{array}{l}\text { A set of three variables describes the farm type. A farm is a livestock operation if } L U>1.5 \text {. To be 'organic livestock', } \\
\text { at least one animal of the } \mathrm{LU}>1.5 \text { has to be organic. Livestock operations without the certification of any animal } \\
\text { are 'conventional livestock'. Farms with } 1.5 \mathrm{LU} \text { or less are categorised as 'only crops'. }\end{array}$ \\
\hline Farm specialisation & Farm specialisation is measured by the Herfindahl index defined as (Schmalensee, 1977): $H=\sum_{p}\left(y_{p}^{s}\right)^{2}$ where $y_{p}^{s}$ is the \\
\hline & $\begin{array}{l}\text { share of the } p \text { th enterprise in the total standard gross margin (SGM) of the farm, calculated per unit area of crops and per } \\
\text { head of livestock using standardised SGM coefficients for each type of crop and livestock. The index ranges from } 0 \text { to } 1 \text {. } \\
\text { A value of } H \text { close to unity indicates specialisation, whereas smaller values reflect increasing diversification. }\end{array}$ \\
\hline
\end{tabular}

\footnotetext{
${ }^{\text {a }}$ Farmland area and livestock numbers are for the last year farmed organically or 2006.
} 
uncertified (uncertified organic deregistrants), (2) farming using conventional practices (conventional deregistrants), and (3) stop farming (farm leavers). Characteristics of farmers who plan to continue certified organic management are not examined in this paper.

A series of one-way analyses of variances (ANOVA) for metric variables (including the 7-point scale variables) and chi-square or Fisher's exact tests for discrete variables were performed to assess differences in the mean values across the three groups. If the overall test for a variable was found to be significant $(p<0.05)$, we employed multiple comparison methods to provide pair-wise comparisons. We used a $t$-test for the mean to look for differences between pairs of groups for continuous variables, and used the Freeman-Tukey test for discrete variables. We adjusted the $p$-values in a step-down fashion by using bootstrap resampling.

We employed an exploratory principal component analysis (PCA) with orthogonal varimax rotation to reduce the items concerning environmental attitudes and reasons for ceasing certification to a smaller number of underlying dimensions. Factor solutions with different numbers of factors were examined before structures were defined in order to have the most representative and simple sets of factors. Scale items with loadings less than 0.40 , significant mixed-factor loadings, or communalities less than 0.50 were evaluated for possible deletion (Hair et al., 2006). We formed summated scales by combining all of the items loading highly on a factor into a single composite measure where these individual items were averaged. We checked for reliability (internal consistency within each dimension) with a series of diagnostic measures. Item-to-total correlations above 0.50 , inter-item correlations more than 0.30 , and a reliability coefficient (Cronbach's alpha) above 0.60 are deemed acceptable in exploratory research (Hair et al., 2006). We used the summated scales as measures in the subsequent regressions.

Some respondents failed to respond to a few items in the multiple-item scales. Our approach for dealing with missing data in these constructs was to delete the few cases lacking more than 50\% of the items within a scale. For the remaining observations, missing data points were replaced with the mean value of the item based on all valid responses in the relevant group.

We performed multiple linear regressions to determine the degree of association between the underlying dimensions of reasons for opting out produced by the factor analysis and the explanatory variables. Farm(er) characteristics and environmental attitudes were used as explanatory variables. Variables with several missing observations were not included in the regression models. We encountered no collinearity problems among the explanatory variables using variance inflation factors and condition indices. White's test was performed and suggested no signs of heteroskedasticity.

We also assessed the qualitative responses in the survey and identified them with underlying themes. The comments complemented the quantitative results, thus providing a richer description of farmers' experiences.

\section{Results and discussion}

\subsection{Current farming status}

Of the 407 certified organic farmers in 2006, eight indicated that they had opted out by November 2007 (Table 2). Fourteen of the 220 deregistrants in 2004-2007 never deregistered or were reclassified, for example, as partnerships in dairy production, or they converted again. Of the 214 respondents indicating they were currently deregistered, 131 (61\%) followed conventional practices, 46 (21\%) were still farming by organic principles, and 37 (17\%) had stopped farming.

Although the true number of deregistrants going out of business may be higher due to the 45 undeliverable surveys, a majority of the deregistrants continue to farm. Sierra et al. (2008) also found that the majority of deregistrants were still farming, though the proportion of respondents in California no longer farming was higher than in our study (36\% compared to 17\%). Interestingly, of those still farming in California, 35\% retained organic methods, somewhat higher than the proportion in Norway (26\%, 46 out of 177).

\subsection{Expected farming status in 5-10 years}

Table 3 shows the cross-tabulation of respondents by expected farming status in 5-10 years and current farming status. Nearly one quarter ( 96 of 413) of the certified organic farmers in 2007 planned to cease certification within 5-10 years. Twenty of the potential deregistrants were planning to exit farming altogether and 76 to continue farming, either conventionally or organically but uncertified. About 75\% (27 of 37) of current farm-leavers, expect (or hope) that the farm will be actively operating again within 5-10 years. We have also noted that 28 farmers deregistered by 2007 would like to become organically certified again.

The remainder of this article examines those 277 farmers who expect to deregister in 5-10 years (sum of the cells in italics in the last row). Of these, 105 (38\%) plan to farm by organic principles but without certification, 139 (50\%) plan to farm using conventional practices, and 33 (12\%) plan to stop farming altogether.

\subsection{Key characteristics}

Mean farmer age was 50.7 years (Table 4). As expected, the farm-leavers were significantly older than the conventional deregistrants. The mean year of conversion was close to 2000 for all groups, though the conventional deregistrants began conversion most recently. Female farmers composed less than $10 \%$ of the respondents. Around 35\% of farmers had higher education, half possessed agricultural education, and half were Extension Service members. Around $40 \%$ of holdings were in a central location, and the same proportion worked off-farm. Only $14 \%$ of farm households earned a high farm income, of these were none farm-leavers.

On average, the farmers cultivated 22.7 ha the last year they farmed organically or in 2006 (Table 4). The conventional

Table 2

Current farming status of all survey respondents.

\begin{tabular}{|c|c|c|c|c|c|}
\hline \multirow[t]{3}{*}{ Original samples } & \multicolumn{5}{|c|}{ Current farming status (Nov. 2007) } \\
\hline & \multirow[t]{2}{*}{ Certified organic } & \multicolumn{3}{|c|}{ Group of deregistrants } & \multirow[t]{2}{*}{ Total } \\
\hline & & Uncertified organic & Conventional & Stopped farming & \\
\hline Certified organic in 2006 & 399 & 3 & 4 & 1 & 407 \\
\hline Deregistered in 2004-2007 & 14 & 43 & 127 & 36 & 220 \\
\hline Total & 413 & 46 & 131 & 37 & 627 \\
\hline
\end{tabular}


Table 3

Expected farming status in 5-10 years by current farming status of all survey respondents.

\begin{tabular}{|c|c|c|c|c|c|c|}
\hline \multirow[t]{3}{*}{ Current farming status } & \multicolumn{6}{|c|}{ Planned farming status } \\
\hline & \multirow[t]{2}{*}{ No response } & \multirow[t]{2}{*}{ Certified organic } & \multicolumn{3}{|c|}{ Group of deregistrants } & \multirow[t]{2}{*}{ Total } \\
\hline & & & Uncertified organic & Conventional & Stopped farming & \\
\hline Certified organic & 9 & 308 & 38 & 38 & 20 & 413 \\
\hline Uncertified organic & 0 & 9 & 31 & 3 & 3 & 46 \\
\hline Conventional & 1 & 7 & 30 & 89 & 4 & 131 \\
\hline Stopped farming & 4 & 12 & 6 & 9 & 6 & 37 \\
\hline Total & 14 & 336 & 105 & 139 & 33 & 627 \\
\hline
\end{tabular}

deregistrants operated significantly more farmland than the other groups, whereas they had the lowest percentage of land in organic production. Around $75 \%$ of the farms were growing organic forage crops. Fewer produced organic grains (19.5\%) or organic horticultural crops (5.8\%). With regard to livestock, $31.4 \%$ of the farms raised sheep and $17.3 \%$ kept dairy cows. Less than half of these herds were certified organic. Organic dairy farming was significantly more common among farm-leavers than among conventional deregistrants.

In total, $43.3 \%$ of the farms were 'conventional livestock', $24.9 \%$ were 'organic livestock', and $31.8 \%$ were 'only crops' (definitions in
Table 1). A significantly larger share of farm-leavers than conventional deregistrants kept organic livestock. The three groups did not differ by the degree of farm specialisation.

About 220 respondents reported a mean percentage of sales through consumer-direct marketing of $13.9 \%$ (Table 4 ). The uncertified organic deregistrants had significantly higher shares of direct sales than the others. Maybe they can inform about the production and build long-run reputations with customers through direct sales, and customers thereby become convinced that the products are as good as organic certified alternatives. Certification may, then, not be worth the burden.

Table 4

Key characteristics and environmental attitudes by planned farming status in 5-10 years.

\begin{tabular}{|c|c|c|c|c|c|c|}
\hline Characteristic $(n=277)$ & Overall mean & Overall SD & Uncertified organic & Conventional & Stopped farming & $p$-Value ${ }^{a}$ \\
\hline \multicolumn{7}{|l|}{ Farmer characteristics } \\
\hline Age (years) & 50.7 & 9.8 & $51.5^{1,2}$ & $49.3^{2}$ & $54.1^{1}$ & 0.026 \\
\hline Year of conversion & 1999.9 & 3.8 & $1999.0^{2}$ & $2000.8^{1}$ & $1999.5^{1}$ & 0.001 \\
\hline Female (\%) & 7.9 & 27.1 & 9.5 & 7.2 & 6.1 & 0.732 \\
\hline Education (\%) & 35.7 & 48.0 & 37.1 & 33.1 & 42.4 & 0.561 \\
\hline Agricultural education (\%) & 53.1 & 50.0 & 51.4 & 56.8 & 42.4 & 0.300 \\
\hline Extension service member (\%) & 50.2 & 50.0 & 49.5 & 53.2 & 39.4 & 0.355 \\
\hline Central location (\%) & 41.9 & 49.4 & 43.8 & 41.7 & 36.4 & 0.750 \\
\hline Off-farm work (\%) & 39.4 & 48.9 & 34.3 & 43.9 & 36.4 & 0.294 \\
\hline High farm income (\%) & 14.1 & 34.8 & $10.5^{2}$ & $20.1^{1}$ & $0.0^{3}$ & 0.005 \\
\hline \multicolumn{7}{|l|}{ Land management ${ }^{\mathrm{b}}$} \\
\hline Farmland (ha) & 22.7 & 21.1 & $20.0^{2}$ & $26.3^{1}$ & $16.3^{2}$ & 0.012 \\
\hline Organic farmland (ha) & 12.8 & 13.7 & 13.9 & 11.7 & 14.0 & 0.428 \\
\hline Land in organic production (\%) & 69.3 & 37.3 & $74.8^{1}$ & $60.6^{2}$ & $88.3^{1}$ & 0.000 \\
\hline Organic horticulture (\% of farms) & 5.8 & 23.4 & 8.6 & 3.6 & 6.1 & 0.256 \\
\hline Organic horticulture (ha) & 0.8 & 0.8 & 1.0 & 0.6 & 0.6 & 0.677 \\
\hline Organic grains (\% of farms) & 19.5 & 39.7 & 13.3 & 23.7 & 21.2 & 0.123 \\
\hline Organic grains (ha) & 9.1 & 10.8 & 11.0 & 9.4 & 3.9 & 0.356 \\
\hline Organic forage crops (\% of farms) & 75.1 & 43.3 & 78.1 & 69.8 & 87.9 & 0.064 \\
\hline Organic forage crops (ha) & 12.9 & 11.3 & 13.8 & 11.8 & 14.1 & 0.424 \\
\hline Stocking rate [LU (ha $\left.\left.\mathrm{UAA}^{-1}\right)\right]$ & 0.75 & 1.42 & 0.89 & 0.68 & 0.61 & 0.419 \\
\hline \multicolumn{7}{|l|}{ Livestock management ${ }^{\mathrm{b}}$} \\
\hline Dairy cows (\% of farms) & 17.3 & 37.9 & 18.1 & 13.7 & 30.3 & 0.074 \\
\hline Organic dairy cows (\% of farms) & 6.5 & 24.7 & $6.7^{1,2}$ & $3.6^{2}$ & $18.2^{1}$ & 0.009 \\
\hline Number of dairy cows & 17.8 & 13.1 & 18.4 & 18.4 & 15.5 & 0.827 \\
\hline Number of organic dairy cows & 19.7 & 19.3 & 25.7 & 18.4 & 13.7 & 0.555 \\
\hline Sheep (\% of farms) & 31.4 & 46.5 & 36.2 & 26.6 & 36.4 & 0.226 \\
\hline Organic sheep (\% of farms) & 12.6 & 33.2 & 13.3 & 10.1 & 21.2 & 0.215 \\
\hline Number of sheep & 52.9 & 47.4 & 55.5 & 57.0 & 32.2 & 0.264 \\
\hline Number of organic sheep & 39.9 & 25.0 & 45.6 & 43.1 & 22.0 & 0.101 \\
\hline \multicolumn{7}{|l|}{ Farm type categories, etc. ${ }^{\mathrm{b}}$} \\
\hline Conventional livestock (\% of farms) & 43.3 & 49.6 & 42.9 & 45.3 & 36.4 & 0.642 \\
\hline Organic livestock (\% of farms) & 24.9 & 43.3 & $27.6^{1,2}$ & $18.7^{2}$ & $42.4^{1}$ & 0.013 \\
\hline Only crops (\% of farms) & 31.8 & 46.6 & 29.5 & 36.0 & 21.2 & 0.215 \\
\hline Farm specialisation (index) & 0.73 & 0.25 & 0.73 & 0.74 & 0.71 & 0.894 \\
\hline \multicolumn{7}{|l|}{ Miscellaneous } \\
\hline Consumer-direct marketing (\% of sales) & 13.9 & 27.2 & $23.6^{1}$ & $8.4^{2}$ & $3.6^{2}$ & 0.000 \\
\hline NEP-scale & 5.10 & 1.29 & $5.40^{1}$ & $4.83^{2}$ & $5.27^{1,2}$ & 0.002 \\
\hline
\end{tabular}

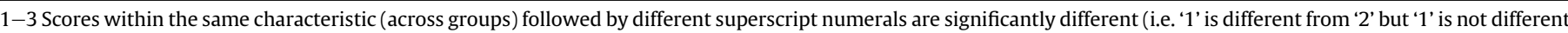
from ' 1,2 '),$p<0.05$.

a One-way ANOVA $p$-values comparing means for metric variables, chi-square or Fisher exact test for discrete variables.

b Mean hectares and livestock numbers refer to the number of farms complying with the definitions for particular types of crops and animals (Table 1). 


\subsection{Environmental attitudes}

We factor analysed the eight NEP-scale statements. Three items associated with low factor loadings or low communality were removed from the final PCA model (Statement Nos. 2, 5, and 8 in Appendix A). This model achieved an overall MSA of 0.79 . One predominant factor explained $54.6 \%$ of the variance. Cronbach's alpha for the remaining items was 0.79 . The high degree of internal consistency among the five NEP-items suggests that it is appropriate to combine them into a single measure of environmental attitudes. These results are consistent with several studies that have also found it expedient to represent the NEP-items by a single dimension (e.g., Dunlap et al., 2000).

Overall, deregistrants appear to be pro-environmentally orientated (Table 4) and uncertified organic deregistrants expressed significantly higher values on the NEP-scale than the conventional deregistrants. Previous studies have consistently found that environmentalists score higher on the NEP-scale than the general public (e.g., Dunlap et al., 2000).

\subsection{Reasons for ceasing certification}

Excessive bureaucracy associated with certification and control stands out as the highest-rated reason for ceasing organic certification (Table 5). Other regulatory issues, including complicated and changing standards, also scored highly. Views on the strictness of the inspections were mixed.

The growth of the organic food industry and its mainstreaming in anonymous retail venues have been associated with the creation of legal and formal standards set by governments and third-party certification (TPC) with inspections of farms in order to facilitate consumer confidence and global trade (e.g., Raynolds, 2004). Many farmers complain about the costs and burdens of the organic TPC regime, the standard setting, and regulatory mechanisms because they typically operate counter to the traditional norms and practices of farmers. Hence, it is not surprising that regulatory issues were the primary reasons for ceasing organic certification.

Unpredictable organic farming policy was also commonly identified as a reason for opting out (Table 5). This finding matches previous studies of organic farmers in Norway in which they perceived institutional factors as primary sources of risk, especially concerning general and organic farming payments (Flaten et al., 2005). Other highly ranked reasons (overall means higher than 4.75) reflected economic issues. Low price premiums and organicsupport payments together with costly inputs were all found to produce poor financial results and high income risk.

Agronomic problems and higher labour requirements were only of intermediate importance in regard to the reasons for opting out. Low yields and weed-related losses ranked highest of the agronomy reasons, whereas control of crop pests and diseases belonged to the lowest ranked reasons among all. The last finding is related to the sparse growing of horticultural crops. Marketing issues were also only of intermediate importance. Several of the items with a low score reflected personal and social issues. A lack of family support, for example, was rated lowest.

Uncertified organic deregistrants attached significantly greater importance than farm-leavers to the bureaucracy attached to certification (Table 5). Items such as financial results and income

Table 5

Reasons for ceasing organic certification by planned farming status in 5-10 years. Ranked in order of overall mean score.

\begin{tabular}{|c|c|c|c|c|c|c|}
\hline Reasons & Overall mean & Overall SD & Uncertified organic & Conventional & Stopped farming & $p$-Value ${ }^{a}$ \\
\hline \multicolumn{7}{|l|}{ All items } \\
\hline Excessive bureaucracy associated with certification and control & 5.75 & 1.72 & $6.06^{1}$ & $5.67^{1,2}$ & $5.12^{2}$ & 0.018 \\
\hline Organic farming payments too low & 5.22 & 1.84 & 4.96 & 5.38 & 5.33 & 0.195 \\
\hline Price premiums too low & 5.18 & 1.95 & 4.87 & 5.32 & 5.58 & 0.098 \\
\hline Unpredictable organic farming policy & 5.15 & 1.86 & 4.96 & 5.29 & 5.18 & 0.401 \\
\hline Complicated organic standards & 5.14 & 1.88 & 5.22 & 5.22 & 4.58 & 0.182 \\
\hline Poor financial results & 5.11 & 1.88 & $4.53^{2}$ & $5.52^{1}$ & $5.21^{1}$ & 0.000 \\
\hline Changes in organic standards & 4.98 & 1.98 & 5.19 & 4.94 & 4.52 & 0.227 \\
\hline High costs of organic inputs & 4.92 & 1.93 & 4.62 & 5.05 & 5.33 & 0.099 \\
\hline High income risk & 4.79 & 1.94 & $4.28^{2}$ & $5.09^{1}$ & $5.15^{1}$ & 0.003 \\
\hline Demotivating that organic produce is sold as non-organic & 4.54 & 2.20 & 4.50 & 4.46 & 5.03 & 0.397 \\
\hline Lower yields than expected & 4.36 & 2.12 & $3.83^{2}$ & $4.82^{1}$ & $4.09^{1,2}$ & 0.001 \\
\hline Weed-related losses & 4.24 & 2.25 & $3.61^{2}$ & $4.59^{1}$ & $4.76^{1}$ & 0.001 \\
\hline Strict inspections & 4.04 & 2.00 & 4.06 & 4.11 & 3.70 & 0.567 \\
\hline High labour requirements & 3.98 & 1.94 & 3.66 & 4.26 & 3.84 & 0.057 \\
\hline The five-year requirement to keep the conversion payment was fulfilled & 3.93 & 2.32 & $3.36^{2}$ & $4.38^{1}$ & $3.82^{1,2}$ & 0.004 \\
\hline Difficulties in finding buyers (for organic products) & 3.90 & 2.33 & 3.86 & 3.85 & 4.18 & 0.756 \\
\hline Arduous management challenges & 3.82 & 2.03 & 3.56 & 4.07 & 3.55 & 0.112 \\
\hline Shortage of manure & 3.60 & 2.29 & 3.37 & 3.78 & 3.61 & 0.397 \\
\hline Lack of network of organic farmers & 3.60 & 2.07 & 3.70 & 3.50 & 3.70 & 0.724 \\
\hline Do not belong to a distinctive organic culture & 3.49 & 2.09 & 3.17 & 3.69 & 3.70 & 0.145 \\
\hline Unfavourable natural conditions & 3.23 & 2.02 & $2.86^{2}$ & $3.60^{1}$ & $2.85^{1,2}$ & 0.010 \\
\hline Lack of advisory service support & 3.14 & 1.96 & 3.18 & 3.03 & 3.42 & 0.557 \\
\hline Organics is not acknowledged in my local environment & 3.11 & 2.03 & 3.05 & 3.15 & 3.12 & 0.934 \\
\hline Changing personal circumstances & 3.04 & 2.25 & $2.92^{2}$ & $2.81^{2}$ & $4.36^{1}$ & 0.001 \\
\hline Lost interest in farming organically & 3.01 & 1.95 & $2.40^{2}$ & $3.55^{1}$ & $2.61^{2}$ & 0.000 \\
\hline Crop pests and diseases & 2.97 & 1.93 & 2.70 & 3.10 & 3.27 & 0.173 \\
\hline Lack of family support & 2.47 & 1.90 & 2.21 & 2.60 & 2.76 & 0.198 \\
\hline \multicolumn{7}{|l|}{ Summated scales $(n=274)^{b}$} \\
\hline Economics & 5.04 & 1.43 & $4.67^{2}$ & $5.27^{1}$ & $5.24^{1,2}$ & 0.004 \\
\hline Regulation & 4.98 & 1.54 & 5.13 & 4.99 & 4.48 & 0.104 \\
\hline Knowledge-exchange & 3.28 & 1.71 & 3.31 & 3.22 & 3.41 & 0.826 \\
\hline Production & 3.70 & 1.52 & $3.25^{2}$ & $4.03^{1}$ & $3.74^{1,2}$ & 0.000 \\
\hline Market access & 4.22 & 2.05 & 4.18 & 4.16 & 4.61 & 0.513 \\
\hline
\end{tabular}

1-3 Scores within the same item (across groups) followed by different superscript numerals are significantly different, $p<0.05$.

a $p$-Values from one-way ANOVA tests of groups.

b See Table 6 for a list of items included in each of the summated scales. 
risk scored significantly higher for the conventional and farmleaver groups than the uncertified organic deregistrants. The item of meeting the five-year requirement in order to keep the conversion payment scored higher among conventional than uncertified organic deregistrants. The conventional deregistrants also scored higher than the uncertified organic deregistrants on a number of the agronomic issues. As expected, farm-leavers ranked personal circumstances higher than the other groups.

Overall, this study supports the results found in recent studies of deregistrants (Kaltoft and Risgaard, 2006; Kirner et al., 2006; Harris et al., 2008; Sierra et al., 2008), namely, that economic challenges and regulatory issues are the dominant reasons leading to deregistration. Since farmers' primary reasons for ceasing organic certification are chiefly the same, the key findings in these studies appear to provide relevant lessons and implications across Western agricultural policy regimes.

\subsection{Factor analysis of reasons for opting out}

Acknowledging that deregistration is a complex process, we asked respondents to rate the reasons that ranged over a wide variety of issues. We were thus also concerned with identifying the underlying patterns in the responses. A PCA was applied to transform the 27 items to a smaller number of factors. The value of the overall MSA was 0.79 for the final solution, which included 18 items. Five factors with eigenvalues greater than unity were identified (Table 6). Each item had a factor loading of 0.50 or higher on only one factor (to be included in the summated scale).

The five factors accounted for $66.1 \%$ of the total variance. The following descriptive labels were given: Economics (factor 1); Regulations (factor 2), Knowledge-exchange (factor 3), Production (factor 4), and Market access (factor 5). The Cronbach's alphas for the five scales (Table 6) were well above the lower limits of acceptability for newly developed scales. The factors, represented by the summated scales, highlighted contrasting reasons for ceasing certification. Economics and Regulations had (as for the individual items) the highest scores of the summated scales overall, Market access and Production had intermediate scores, and Knowledge-exchange produced the lowest score (Table 5). The mean Economics and Production scores were higher for conventional deregistrants than for uncertified organic deregistrants.

\subsection{Voluntary responses}

Some 127 of the 277 deregistrants provided voluntary responses at the end of the survey, mostly additional descriptions on reasons for opting out. These responses generally support the quantitative findings, with a range of regulatory issues described. The farmers gave a number of similar explanations, for example, 'too many organic rules are changed after just a few years, which makes them messy and confusing'; 'some inspectors seem to have a personal ambition of enforcing the organic standards as rigidly and inflexibly as possible'; 'the only factor I disliked was the organic standards; too little was left to individual judgment'; and 'control-documentation-red-tape-top-bottom communication-take away much of the pleasure of rural life'. A number of farmers also described severe agronomic problems, with weedy fields being the most common.

\subsection{Attributes associated with dimensions of reasons to opt out}

Multiple linear regressions performed on the five factors of reasons to opt out produced three statistically significant models (Table 7). For the statistically significant models, the adjusted $R^{2}$ ranged from $11 \%$ (Regulations) to $17 \%$ (Economics). The regression
Table 6

Reasons for ceasing organic certification: Varimax rotated factor matrix.

\begin{tabular}{|c|c|c|c|c|c|c|}
\hline \multirow[t]{2}{*}{ Scale items $(n=274)$} & \multicolumn{5}{|c|}{ Varimax rotated loadings $^{\mathrm{a}}$} & \multirow[t]{2}{*}{ Communality } \\
\hline & 1 & 2 & 3 & 4 & 5 & \\
\hline \multicolumn{7}{|l|}{ Economics $(\alpha=0.82)^{\mathrm{b}}$} \\
\hline Poor financial results & 0.80 & 0.02 & 0.02 & 0.28 & 0.10 & 0.73 \\
\hline $\begin{array}{l}\text { Organic farming payments } \\
\text { too low }\end{array}$ & 0.77 & 0.20 & 0.13 & -0.03 & 0.06 & 0.65 \\
\hline $\begin{array}{l}\text { Unpredictable organic } \\
\text { farming policy }\end{array}$ & 0.69 & 0.35 & 0.08 & -0.07 & 0.18 & 0.63 \\
\hline High income risk & 0.62 & 0.09 & 0.18 & 0.34 & 0.19 & 0.57 \\
\hline Cost of inputs & 0.61 & 0.24 & 0.17 & 0.16 & 0.11 & 0.49 \\
\hline \multicolumn{7}{|l|}{ Regulations $(\alpha=0.83)$} \\
\hline $\begin{array}{l}\text { Complicated organic } \\
\text { standards }\end{array}$ & 0.16 & 0.87 & 0.05 & 0.08 & 0.07 & 0.80 \\
\hline $\begin{array}{l}\text { Excessive bureaucracy } \\
\text { associated with } \\
\text { certification and control }\end{array}$ & 0.09 & 0.83 & -0.02 & -0.07 & 0.01 & 0.70 \\
\hline Changes in organic standards & 0.15 & 0.79 & 0.06 & 0.06 & 0.16 & 0.68 \\
\hline Strict inspections & 0.22 & 0.65 & 0.27 & -0.04 & -0.08 & 0.56 \\
\hline \multicolumn{7}{|l|}{ Knowledge-exchange $(\alpha=0.80)$} \\
\hline $\begin{array}{l}\text { Lack of network of organic } \\
\text { farmers }\end{array}$ & 0.23 & 0.01 & 0.84 & 0.10 & 0.15 & 0.79 \\
\hline $\begin{array}{l}\text { Organics is not acknowledged } \\
\text { in my local environment }\end{array}$ & 0.09 & 0.13 & 0.81 & 0.12 & 0.14 & 0.72 \\
\hline $\begin{array}{l}\text { Lack of advisory service } \\
\text { support }\end{array}$ & 0.07 & 0.12 & 0.77 & 0.16 & 0.01 & 0.64 \\
\hline \multicolumn{7}{|l|}{ Production $(\alpha=0.71)$} \\
\hline Weed-related losses & 0.06 & -0.01 & -0.01 & 0.81 & 0.09 & 0.67 \\
\hline Crop pests and diseases & -0.02 & 0.15 & 0.17 & 0.80 & 0.09 & 0.70 \\
\hline Lower yields than expected & 0.40 & -0.08 & 0.11 & 0.59 & -0.02 & 0.52 \\
\hline $\begin{array}{l}\text { Unfavourable natural } \\
\text { conditions }\end{array}$ & 0.24 & -0.09 & 0.24 & 0.55 & -0.14 & 0.45 \\
\hline \multicolumn{7}{|l|}{ Market access $(\alpha=0.79)$} \\
\hline Difficulties in finding buyers & 0.15 & 0.03 & 0.14 & 0.06 & 0.87 & 0.81 \\
\hline \multirow{2}{*}{$\begin{array}{l}\text { Demotivating that organic } \\
\text { produce is sold as } \\
\text { non-organic }\end{array}$} & 0.21 & 0.11 & 0.10 & 0.01 & 0.86 & 0.80 \\
\hline & & & & & & Total \\
\hline Sum of squares (eigenvalue) & 2.91 & 2.80 & 2.25 & 2.24 & 1.70 & 11.90 \\
\hline Percentage of variance (\%) & 16.2 & 15.5 & 12.5 & 12.4 & 9.5 & 66.1 \\
\hline
\end{tabular}

model related to the Knowledge-exchange and Market access factors were insignificant, suggesting that perceptions of these factors are very personal or that important variables associated with farmers' perceptions have been excluded from our analysis. To facilitate a direct comparison of the effects across explanatory variables measured in different units, the standardised coefficients are presented.

A recent year of conversion was the strongest predictor of the Economics dimension when we controlled for other variables. This finding may be related to trends towards more pragmatic and business-oriented farming practices among those converting lately (Flaten et al., 2006), as this pragmatism may extend to a greater willingness to jettison organic farming if financial outcomes become poorer than expected (e.g. Harris et al., 2008). The farm type of 'only crops' (negative value, less important for them), increased farm specialisation, being an uncertified organic deregistrant, low environmental concerns (NEP) and low farm income were also significant catalysts for Economics. In contrast to the bivariate analysis (Table 5), the regression analysis showed that uncertified organic deregistrants scored higher on the Economics factor than conventional deregistrants. This result demonstrates that the combined effects of variables may be overlooked in bivariate analyses. 
Table 7

Multiple linear regressions of attributes on factors of reasons to opt out.

\begin{tabular}{|c|c|c|c|c|c|}
\hline Explanatory variables $(n=256)$ & Economics & Regulations & Knowledge-exchange & Production & Market access \\
\hline Age (years) & 0.09 & 0.11 & 0.04 & -0.03 & 0.09 \\
\hline Year of conversion & $0.27^{* * *}$ & 0.09 & 0.08 & $0.15^{*}$ & -0.10 \\
\hline Gender $($ female $=1$ ) & 0.08 & -0.03 & 0.06 & 0.04 & -0.01 \\
\hline Education $($ BSc or higher $=1$ ) & 0.05 & 0.02 & -0.07 & -0.01 & $-0.15^{*}$ \\
\hline Agricultural education $(=1)$ & -0.06 & 0.01 & -0.08 & 0.01 & -0.09 \\
\hline Extension service member $(=1)$ & -0.03 & $-0.18^{* *}$ & -0.06 & 0.08 & -0.07 \\
\hline Location (central = 1) & -0.01 & 0.01 & -0.03 & 0.01 & 0.00 \\
\hline Off-farm work $(=1)$ & -0.06 & -0.04 & -0.01 & -0.11 & -0.02 \\
\hline High farm income $(=1)$ & $-0.14^{*}$ & -0.06 & -0.05 & -0.04 & -0.03 \\
\hline Farmland (ha) & 0.13 & 0.11 & 0.03 & -0.06 & 0.08 \\
\hline Land in organic production (\%) & 0.11 & -0.01 & 0.10 & -0.08 & -0.08 \\
\hline Stocking rate [LU $\left(\right.$ ha $\left.\left.U_{A A}^{-1}\right)\right]$ & 0.00 & -0.11 & 0.03 & 0.05 & 0.03 \\
\hline Organic livestock $(=1)^{\mathrm{a}}$ & -0.02 & 0.12 & -0.04 & $-0.16^{*}$ & 0.01 \\
\hline Only crops $(=1)^{\mathrm{a}}$ & $-0.24^{* *}$ & $-0.28^{* * *}$ & -0.10 & -0.02 & -0.02 \\
\hline Farm specialisation (index) & $0.19^{* *}$ & $0.16^{*}$ & 0.07 & 0.07 & $0.20^{*}$ \\
\hline NEP-scale & $-0.15^{*}$ & -0.12 & $-0.17^{*}$ & $-0.23^{* * *}$ & -0.00 \\
\hline Plan to opt out $(=1)^{\mathrm{b}}$ & 0.02 & -0.05 & -0.00 & 0.10 & 0.02 \\
\hline Uncert. organic deregistrant $(=1)^{c}$ & $0.18^{* *}$ & -0.05 & -0.03 & $0.15^{*}$ & 0.01 \\
\hline Stopped farming $(=1)^{\mathrm{c}}$ & 0.07 & $-0.19^{* *}$ & -0.02 & 0.11 & 0.05 \\
\hline$F$-value & $3.70^{* * *}$ & $2.63^{* * *}$ & 1.26 & $3.05^{* * *}$ & 1.13 \\
\hline$R^{2}$ & 0.230 & 0.175 & 0.092 & 0.197 & 0.083 \\
\hline$R_{\mathrm{adj}}^{2}$ & 0.168 & 0.109 & 0.019 & 0.132 & 0.010 \\
\hline
\end{tabular}

${ }^{*} p<0.05 ;{ }^{* *} p<0.01 ;{ }^{* * *} p<0.001$. Standardised regression coefficients.

a Farm type measured as dummy variables where 'conventional livestock' is the reference category (0), and 1 denotes 'organic livestock' and 'only crops', respectively.

b Measured as a dummy variable where 1 denotes plans to cease certified organic production within $5-10$ years; 0 otherwise (i.e., currently deregistered).

c Expected farming status in 5-10 years measured as dummy variables where 'conventional deregistrant' is the reference category ( 0 ), and 1 denotes 'uncertified organic deregistrant' and 'stopped farming', respectively.

Farm type was the strongest predictor for Regulations. The group of 'only crops' found them easiest, whereas the group of 'organic livestock' perceived the burden of regulation to be heaviest (tendency, $p=0.09$ ). It is likely that this finding is related to the large number and complexity of regulations for organic livestock farmers and livestock farmers who just farm the land organically. For instance, several organic livestock regulations have recently been changed, sometimes in ambiguous and unpredictable ways, including the withdrawal of announced changes. Several comments from the farmers cited problems with organic livestock requirements related to, for instance, loose housing systems for dairy cows, access to an open-air exercise area for bulls, $100 \%$ organic feeds, and solid floors in the indoor housing period for sheep. An instructive farmer response was: 'Ceased organic certification at the turn of the year 2004/2005 owing to the requirement of solid floor for the sheep. The costs would have been too high. In August 2005, Debio informed me that the solid floor requirement was withdrawn. The "happy" news arrived too late. The organic standards have always been too unpredictable'.

Farm-leavers found Regulations less important than the others did. Regulatory problems were also positively associated with no extension service membership, and farm specialisation. For Production, low environmental concerns was the strongest, followed by organic livestock (negative), recent year of conversion and uncertified organic deregistrant (positive).

Five explanatory variables had significant effects $(p<0.05)$ across two of the three significant models: recent year of conversion, 'only crops' (negative), increased farm specialisation, environmental attitude (positive), and being an uncertified organic deregistrant (positive). Although environmentally oriented farmers scored lower on these factors, it does not appear to prevent them from opting out. Specialised farmers struggled most with the primary reasons for opting out, that is, Economics and Regulations. It may be that more on-farm diversification would have moderated these problems, thereby making it easier to continue farming organically. Interestingly, characteristics such as farmer age, gender, education, agricultural education, location, off-farm work, farmland, percentage of land in organic production, stocking rates, and plans to opt out did not show any statistical significant effects in the models tested.

\section{Conclusions and implications}

While there has been considerable debate and research surrounding the adoption of organic farming methods, studies of farmers ceasing or planning to cease organic production have been more limited. This Norwegian study indicates that farmers will continue to opt out, with nearly one in four organic farmers in our 2007-survey reporting that they planned to cease certification within the next 5-10 years. We also found that deregistrants were roughly four times more likely to continue farming than to leave farming entirely.

A surprisingly large number of the deregistrants plan to still farm by organic principles. These farmers cannot market their products as organic, and they will not receive any organic premium prices or organic farming payments. In Sweden, however, lands managed organically but not certified are given agri-environmental support payments (Stolze and Lampkin, 2009). A policy of supporting uncertified organically managed lands is one way to acknowledge wider environmental and social gains. Meanwhile, policy-makers' targets for organic production across most of Europe are linked to certification.

To reach the ambitious goals for organic production set by many governments, it may be more efficient to reduce the number of farmers ceasing organic certification than to use instruments designed to attract newcomers, who often lack experience in organic farming methods. Hence, policymakers would do well by paying attention to the responses from farmers about their reasons for ceasing organic production in order to reduce the number of deregistrants.

Initiatives for helping farmers to cope better with the major drivers behind the decision to opt out (that is, economics and regulations) appear to be essential for retaining in organic production those who plan to continue farming. We do not discuss 
here the decisions to exit farming altogether because they are more closely linked to personal factors and policies that affect the context of farming more generally.

Our findings offer some guidance on how to tailor economic incentives. For example, rather than providing more support to all organic farms, irrespective of their needs or interests, it may be appropriate to provide better-targeted support. The survey responses indicated, for instance, that the call for additional support is smallest among crop farmers. The large number of deregistrants who did not manage their livestock organically suggests that organic livestock payments should increase relative to organic-grassland payments. Higher output prices or lower input prices, primarily through private-sector initiatives to facilitate market innovations, could also encourage more farmers to remain organic.

What can help reduce the red-tape facing organic farmers? It is a challenge that farmers typically favour simplification, the use of common sense, and a reliance on trust, whereas organic production implies enlarged burdens of documentation, costly control procedures, and rigid, complex, and shifting standards. The Norwegian certification body has already taken actions to introduce more userfriendly routines. The latest Norwegian organic action plan includes a proposal for cheaper certification fees (LMD, 2009). Other options may include less frequent on-farm inspections, especially in settings where there is a low likelihood of fraud, greater use of farmers' personal assurances, and better coordination with other farm quality-assurance schemes. Nevertheless, the advice given to farmers who are considering organic certification should make it clear that additional regulatory burdens are an inevitable consequence of a conversion.

Those involved in organic legislation should also be cautious about making changes in standards too frequently, suddenly, and unpredictably. Changes in standards should be announced well before their implementation, and those requiring major investment (e.g., to improve animal welfare) should, when possible, fit into the ordinary investment cycle of the assets involved. Alternatively, investment subsidies could assist in this regard.

Governments also need to be alert to the dilution of standards and dubious farming practices (cf. Guthman, 2004). For example, some farmers in our study were planning to deregister and undergo new conversion on the same land within a few years (Table 3). During the intervening period, these farmers can legally apply pesticides. In order to maintain the integrity of organic production, the enforcement of a period of several years before deregistered land is eligible for organic certification again could be advisable. The regulatory challenge is to design standards that both maintain the integrity of organic ideals and consumer faith and do not come across to farmers as unnecessarily bureaucratic.

Some regulatory problems are associated with the evolution of governmental standards and TPC away from the organic grassroots movements. Although successful with respect to growth and trade, mainstream organics have entered a more complex political environment. In this regard, original ideas about organic agriculture as a way of life, as something much more complex than a set of proscribed and permitted agricultural inputs, have fallen by the wayside, and farmers are now struggling with the burdens of certification (e.g., Mutersbaugh et al., 2005). Yet, two emerging alternatives to the prevailing TPC may help reduce regulatory barriers: Group Certification with an Internal Control System (ICS) and Participatory Guarantee Systems (PGS), both of which provide sound certification that ensures the credibility of organic products (Luttikholt, 2007). The certification group itself operates an ICS. The central component of the ICS is the periodical inspection of individual group members. The TPC is thus reduced to an audit of the ICS, as well as to a few spot-check reinspections of farms. PGSs are locally focused quality-assurance systems. Producers are certified using the active participation of stakeholders, and the system is built on a foundation of trust, social networks, and knowledge-exchange. Inspections are based on peer reviews and social control.

The South is leading with regard to the alternative certification systems (IFOAM, 2009; Nelson et al., 2010). In Norway, the PGS approach may be particularly appealing for deregistrants who retain organic methods and who are involved in consumer-direct marketing. One barrier is the lack of recognition of PGSs within the current legal framework that governs organics in Europe. Members of European PGSs, such as the French association Nature et Progrès, can currently only sell their products as organic if they are also certified by an officially recognised TPC.

This study has used quantitative techniques to examine farmers' reasons for ceasing organic certification. There are several possible extensions to this research. Topic-focused qualitative studies would help us to gain a sharpened understanding of farmers' reflections on opting out, and to understand better the deeper reasons behind their decision. For support of organic farming to be effective, theory-driven research comparing organic and deregistered farmers is also vital for understanding farmers' choice of staying or opting out of organic certification.

\section{Acknowledgments}

The authors are grateful to J. Brian Hardaker, Steven Connolley, two anonymous reviewers and the Editor for their helpful comments and suggestions. They also acknowledge the financial assistance of the Research Council of Norway and the Agricultural Agreement Research Fund, and the valuable cooperation of the farmers who participated in the survey.

\section{Appendix A. Responses to the NEP statements.}

\begin{tabular}{|c|c|c|c|}
\hline Item & Statement & Mean & SD \\
\hline 1 & $\begin{array}{l}\text { The balance of nature is very } \\
\text { delicate and easily upset }\end{array}$ & 5.39 & 1.56 \\
\hline 2 & $\begin{array}{l}\text { Humans have the right to modify } \\
\text { the natural environment to suit their needs }{ }^{\mathrm{a}}\end{array}$ & 2.45 & 1.61 \\
\hline 3 & Humans are severely abusing the environment & 5.07 & 1.86 \\
\hline 4 & $\begin{array}{l}\text { The so-called 'ecological crisis' } \\
\text { facing human kind has } \\
\text { been greatly exaggerated }\end{array}$ & 3.25 & 1.96 \\
\hline 5 & $\begin{array}{l}\text { Plants and animals have } \\
\text { as much right as humans to exist }\end{array}$ & 5.08 & 1.88 \\
\hline 6 & $\begin{array}{l}\text { The balance of nature is strong enough } \\
\text { to cope with the impacts } \\
\text { of modern industrial nations }{ }^{\mathrm{a}}\end{array}$ & 2.47 & 1.54 \\
\hline 7 & $\begin{array}{l}\text { If things continue on their present course, } \\
\text { we will soon experience } \\
\text { a major ecological catastrophe }\end{array}$ & 4.82 & 1.89 \\
\hline 8 & $\begin{array}{l}\text { Human ingenuity will insure that } \\
\text { we do not make the earth unliveable }\end{array}$ & 3.55 & 1.73 \\
\hline
\end{tabular}

${ }^{a}$ Before construction of the scale, ordering were reversed for this statement.

\section{References}

Constance, D.H., Choi, J.Y., 2010. Overcoming the barriers to organic adoption in the United States: a look at pragmatic conventional producers in Texas. Sustainability 2, 163-188.

Debio, 2010. Statistikk 2009. Debio. http://debio.no/_upl/statistikkhefte_2009.pdf (accessed 21.04.10).

Dunlap, R.E., Van Liere, K.D., Mertig, A.G., Jones, R.E., 2000. Measuring endorsement of the new ecological paradigm: a revised NEP scale. J. Soc. Issues $56,425-442$. 
Flaten, O., Lien, G., Koesling, M., Valle, P.S., Ebbesvik, M., 2005. Comparing risk perceptions and risk management in organic and conventional dairy farming: empirical results from Norway. Livest. Prod. Sci. 95, 11-25.

Flaten, O., Lien, G., Ebbesvik, M., Koesling, M., Valle, P.S., 2006. Do the new organic producers differ from the 'old guard'? Empirical results from Norwegian dairy farming. Renew. Agric. Food Syst. 21, 174-182.

Flyvbjerg, B., 2006. Five misunderstandings about case-study research. Qual. Inq. 12, 219-245.

Guthman, J., 2004. Agrarian Dreams: The Paradox of Organic Farming in California. University of California Press, Berkeley and Los Angeles.

Hair Jr., J.F., Black, W.C., Babin, B.J., Anderson, R.E., Tatham, R.L., 2006. Multivariate Data Analysis, sixth ed. Pearson Education, Upper Saddle River.

Harris, F., Robinson, G.M., Griffiths, I., 2008. A study of the motivations and influences on farmers' decisions to leave the organic farming sector in the United Kingdom. In: Robinson, G.M. (Ed.), Sustainable Rural Systems: Sustainable Agriculture and Rural Communities. Ashgate, Aldershot, pp. 99-111.

IFOAM, 2009. An Overview of Established PGS Worldwide. IFOAM. http://www. ifoam.org/about_ifoam/standards/pgs/pdfs/TheGlobalPGSNewsletterNo1October2009.pdf (accessed 07.06.10).

Kaltoft, P., Risgaard, M.-L., 2006. Has organic farming modernized itself out of business? Reverting to conventional methods in Denmark. In: Holt, G., Reed, M. (Eds.), Sociological Perspectives of Organic Agriculture: From Pioneer to Policy. CAB International, Wallingford, pp. 126-141.

Kirner, L., Vogel, S., Schneeberger, W., 2006. Intended and actual behavior of organic farmers in Austria after a five-year commitment period. Renew. Agric. Food Syst. 21, 95-105.

Koesling, M., Flaten, O., Lien, G., 2008. Factors influencing the conversion to organic farming in Norway. Int. J. Agric. Resour., Governance Ecol. 7, 78-95.

LMD (Ministry of Agriculture and Food), 2009. Økonomisk, agronomisk—økologisk! Handlingsplan for å nå målet om 15 pst. økologisk produksjon og forbruk i 2015. Landbruks- og matdepartementet, Oslo.
Luttikholt, L.W.M., 2007. Principles of organic agriculture as formulated by the International Federation of Organic Agriculture Movements. NJAS-Wageningen J. Life Sci. 54, 347-360.

Mattilsynet, 2009. Veileder B: Utfyllende informasjon om økologisk landbruksproduksjon. Mattilsynet, Oslo.

Mutersbaugh, T., Klooster, D., Renard, M.-C., Taylor, P., 2005. Certifying rural spaces: quality-certified products and rural governance. J. Rural Stud. 21, 381-388.

Nelson, E., Tovar, L.G., Rindermann, R.S., Cruz, M.A.G., 2010. Participatory organic certification in Mexico: an alternative approach to maintaining the integrity of the organic label. Agric. Hum. Values 27, 227-237.

Raynolds, L.T., 2004. The globalization of organic agro-food networks. World Dev. 32, 725-743.

Rigby, D., Young, T., Burton, M., 2001. The development of and prospects for organic farming in the UK. Food Policy 26, 599-613.

Schmalensee, R., 1977. Using the H-index of concentration with published data. Rev. Econ. Stat. 59, 186-193.

Sierra, L., Klonsky, K., Strochlic, R., Brodt, S., Molinar, R., 2008. Factors Associated with Deregistration Among Organic Farmers in California. California Institute for Rural Studies, Davis, California.

Skogen, K., Thrane, C., 2008. Wolves in context: using survey data to situate attitudes within a wider cultural framework. Soc. Nat. Resour. 21, 17-33.

SLF (The Norwegian Agricultural Authority), 2010. Produksjon og omsetning av økologiske landbruksvarer. Rapport for 2009, Rapport-nr.: 7/2010, Statens landbruksforvaltning, Oslo.

Stolze, M., Lampkin, N., 2009. Policy for organic farming: rationale and concepts. Food Policy 34, 237-244.

Toma, L., Mathijs, E., 2007. Environmental risk perception, environmental concern and propensity to participate in organic farming programmes. J. Environ. Manage. 83, 145-157.

Willer, H., Kilcher, L. (Eds.), 2010. The World of Organic Agriculture. Statistics and Emerging Trends 2010. IFOAM/FiBL, Bonn/Frick. 